\title{
Blue carbon conservation in West Africa: a first assessment of feasibility
}

\author{
Tanya Bryan ${ }^{1} \cdot$ John Virdin ${ }^{2} \cdot$ Tibor Vegh $^{2}$ (D) $\cdot$ Connie Y. Kot ${ }^{3} \cdot$ Jesse Cleary ${ }^{3} \cdot$ Patrick N. Halpin $^{3}$
}

Received: 8 November 2018 /Revised: 26 November 2019 / Accepted: 4 December 2019 / Published online: 30 January 2020

(C) The Author(s) 2020

\begin{abstract}
The loss of blue carbon ecosystems results in significant levels of carbon emissions and decreased supply of other ecosystem services. West Africa contains approximately $14 \%$ of the world's mangrove area but despite $25 \%$ of coverage loss between 1980 and 2006, the region's mangroves have not been well studied. This study aims to provide a first step toward increasing the knowledge of the region's blue carbon stocks, with a focus on mangroves, and of their financial value based on their carbon storage benefit alone. The best available data suggest that the region contains 1.97 million hectares of mangroves storing 854 million metric tons of carbon in above- and below-ground biomass and the top meter of soil; 4.8 million hectares of seagrass storing 673 million metric tons of carbon; and 1.2 million hectares of salt marshes storing 303 million metric tons of carbon. Even without including values for other benefits of intact mangroves, the conservation of mangroves in the region appears viable. Specifically, the discounted value of 20 -year emission reductions under a conservation scenario is estimated to be between $\$ 341.2-569.0$ million at an $8 \%$ discount rate and carbon prices of $\$ 3$ and $\$ 5$ per metric ton respectively.
\end{abstract}

Keywords Mangrove $\cdot$ Ecosystem service $\cdot$ Sequestration $\cdot$ Biomass $\cdot$ Protected area

\section{Introduction}

Coastal vegetated ecosystems, such as mangrove forests, seagrass meadows and salt marshes, have long provided benefits to human communities and fisheries, and in recent years have been recognized for the significant amounts of carbon (C) that they store and hence their contributions to mitigating climate change (Nellemann and Corcoran 2009; Barbier 2011). At the same time, these ecosystems are being converted rapidly, with current trends projected to lead to 30 to $40 \%$ loss of tidal marshes and sea grasses over the next 100 years, and a loss of nearly all unprotected mangroves (Pendleton et al. 2012). The $C$ stored in these habitats is collectively known as 'blue carbon' (BC). Efforts to conserve coastal vegetated habitats and reduce $\mathrm{C}$ emissions from their conversion have

Tibor Vegh

tibor.vegh@duke.edu

1 GRID-Arendal, Arendal, Norway

2 Nicholas Institute for Environmental Policy Solutions, Duke University, Durham, NC, USA

3 Marine Geospatial Ecology Lab (MGEL), Nicholas School of the Environment, Duke University, Durham, NC, USA increased over the last 5 to 6 years, notably in the case of mangrove forests, as the international community has developed mechanisms to pay tropical countries to reduce greenhouse gas (GHG) emissions from deforestation. These sources of international finance could potentially help tropical countries, where most of the world's mangroves are found, to leverage global capital to fund the economic and financial costs of mangrove conservation, while capturing local benefits such as flood protection and fisheries support, among others.

\section{The global value of mangroves}

Mangrove ecosystems have social, cultural, aesthetic, economic, and financial values. Of the previously identified social and cultural values, the most studied are those for food and food processing, medicinal values and values associated with culture and tradition. With regard to economic values, the most studied is the $\mathrm{C}$ sequestration and storage capacity of these ecosystems because of the aforementioned climate connection. In the last decade, a number of assessments have shown the capacity of intact mangrove forests and other coastal vegetated habitats to store $\mathrm{C}$ at rates that surpass tropical forests with high burial rates on the order of $108 \mathrm{Tg}$ (teragram; $1 \mathrm{Tg}$ equals $1,000,000$ metric tons) $\mathrm{C}$ per year (Duarte, Middleburg et al. 2004; Nellemann and Corcoran 2009; 
Murray et al. 2011, Murray 2012, Alongi 2014). Though mangroves and other marine vegetated habitats occupy only some $0.2 \%$ of the global ocean surface, they contribute half of oceanic C burial (Duarte, Losada et al. 2013).

Given this large storage capacity, globally significant levels of $\mathrm{C}$ emissions result from mangrove deforestation due to coastal population growth and urbanization (Nellemann and Corcoran 2009; Pendleton et al. 2012). From the estimated 49 million hectares of mangroves and other coastal vegetated habitats worldwide, over $1850 \mathrm{Mg}$ (megagram; $1 \mathrm{Mg}$ equals 1 metric ton) $\mathrm{CO}_{2}$ (C dioxide) per hectare are susceptible to release (Pendleton et al. 2012). The global economic damages resulting from global $\mathrm{BC}$ emissions are estimated at the high end on the order of some US\$41 billion annually (Table 1), using a social cost of $\mathrm{C}$ value of US $\$ 40$ per ton of $\mathrm{CO}_{2}$ emissions (EPA 2015).

To put BC emissions into more familiar terms, currently an estimated $1.9 \%$ of mangroves are lost each year globally, resulting in $240 \mathrm{Tg}$ of $\mathrm{CO}_{2}$ emissions - equivalent to emissions from the use of 588 million barrels of oil or from 50.5 million passenger vehicles for example (Pendleton et al. 2012; Herr et al. 2015). Given this benefit of BC sequestration and storage that mangroves and other coastal vegetated habitats provide to the international community, numerous governments, communities, companies and civil society around the world are increasingly supporting their conservation as a climate change mitigation strategy (Herr et al. 2015).

These efforts crystallized in late 2015 with the adoption by the United Nations General Assembly of a new set of Sustainable Development Goals (SDGs), including SDG 13 to take urgent action to combat climate change and its impacts, and SDG 14 to conserve and sustainably use the oceans, seas and marine resources for sustainable development. Mangrove conservation would support the SDG 13 target to "strengthen resilience and adaptive capacity to climate-related hazards and natural disasters in all countries" and SDG 14 target to "by 2020 , sustainably manage and protect marine and coastal ecosystems to avoid significant adverse impacts, including by strengthening their resilience, and take action for their

Table 1 Global BC emissions and resulting economic damages

\begin{tabular}{|c|c|c|c|c|c|c|}
\hline \multirow[t]{2}{*}{ Ecosystem } & \multicolumn{3}{|c|}{$\mathrm{C}$ emissions $\left(\mathrm{Pg} \mathrm{CO}_{2} \mathrm{yr}^{-1}\right)$} & \multicolumn{3}{|c|}{$\begin{array}{l}\text { Economic damages (Billion } \\
\text { USD } \mathrm{yr}^{-1} \text { ) }\end{array}$} \\
\hline & \multicolumn{2}{|c|}{$\begin{array}{l}90 \% \text { confidence } \\
\text { interval }\end{array}$} & Median & Low & High & Median \\
\hline Salt marsh & 0.02 & 0.24 & 0.06 & 0.8 & 9.6 & 2.4 \\
\hline Mangroves & 0.09 & 0.45 & 0.24 & 3.6 & 18.0 & 9.6 \\
\hline Seagrasses & 0.05 & 0.33 & 0.15 & 2.0 & 13.2 & 6.0 \\
\hline Total & 0.15 & 1.02 & 0.45 & 6.0 & 40.8 & 18.0 \\
\hline
\end{tabular}

Source: Pendleton et al. 2012, EPA 2015 restoration in order to achieve healthy and productive oceans (United Nations 2015a)." Additionally, the United Nations Conference on Climate Change (COP) 21 Paris Agreement in December 2015 to hold the increase in global average temperature to well below 2 degrees Celsius above pre-industrial levels, could lead to an increase in the urgency of mangrove conservation.

\section{The importance of West Africa's mangroves}

From the southern border of Mauritania down to the northern border of Angola, West Africa's extensive mangrove forests (Fig. 1) provide a wide range of sustainable benefits to coastal communities and countries, including supporting fisheries, protecting towns and structures from flooding and erosion, as well as a range of cultural and spiritual benefits. This region contains approximately $11 \%$ of the world's mangrove area (Corcoran et al. 2007). Mangroves in the region are believed to be in decline, with estimates suggesting some $25 \%$ lost in the region between 1980 and 2006 (Corcoran et al. 2007), or at an average annual rate of $2-7 \%$ in terms of $\mathrm{C}$ sink (USAID et al. 2014).

The intense human pressure on the mangroves of West Africa are partly due to coastal population densities in some of the top mangrove countries. Mangroves in the ecological zone termed the Afro-tropical realm (which includes WestAfrica) are facing the highest mean human influence index scores of any biome in the region and rank 6th highest out of 50 biomes (Sanderson, Jaiteh et al. 2002). Population densities translate to pressures on a coastal ecosystem by ways of conversion due to urban development and sprawl, infrastructure and related pollution on land (roads and houses) and on the coast (ports). These pressures in West Africa also tend to be concentrated near areas of large $\mathrm{BC}$ stocks.

Beyond these immediate pressures of increasing coastal population densities, West Africa is also heavily dependent on the region's ocean economy which includes fisheries, shipping, offshore oil, and subsistence among others. For example, in terms of fisheries some of the world's richest fishing grounds can be found in the large marine ecosystems off of the coast of West Africa, due to highly productive waters fed by nutrient-rich upwelling currents in certain areas. Many of the region's fisheries depend on mangroves to provide nursery areas and food sources for key species. In the case of mangrove forests, $39 \%$ of capture fish harvest has a life cycle dependent on mangroves (Huxham et al. 2015). Rönnbäck (1999) estimates that annual market value of fisheries supported by mangroves ranges from $\$ 750-16,750$ / ha, with a significant share of this coming from subsistence (e.g., 10-20\% in Sarawak, 56\% in Fiji, and 90\% in Kosrae). Fishing intensity-both commercial and subsistence-is highest along the coasts of Mauritania, Senegal, and Guinea, as 


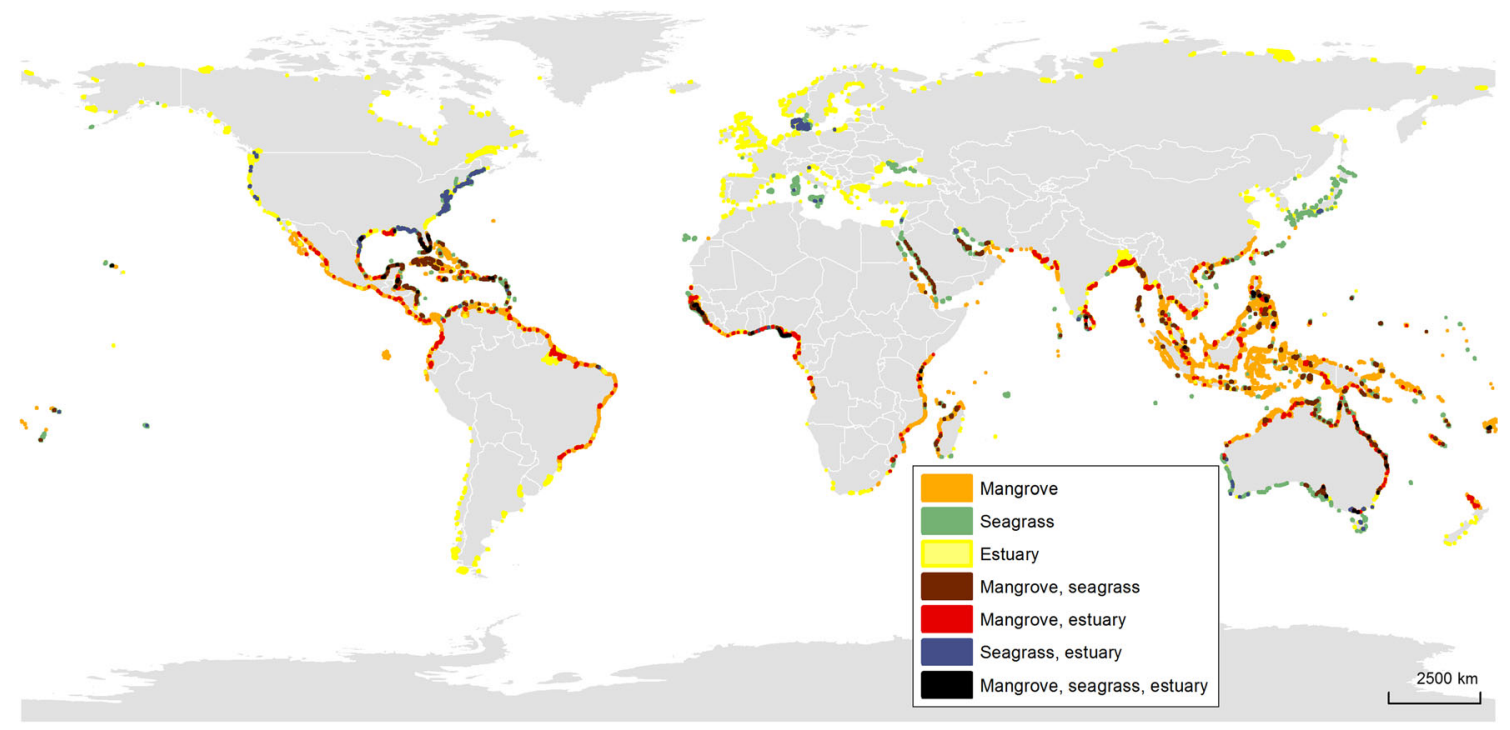

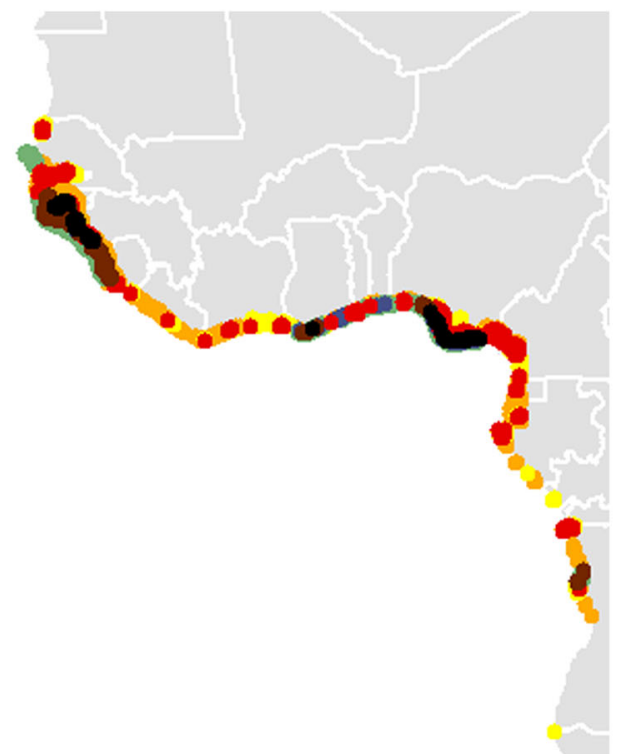

Fig. 1 Global (top) and West African (bottom) distribution of sea grasses, salt marshes, and mangroves, or 'BC'. Note: Estuary coverage is used as an approximation for salt march coverage. Source: USGS Global Distribution of Mangroves (Giri et al. 2011), UNEP WCMC Global

well as from Cote d'Ivoire east to Cameroon. These areas also coincide with major shipping routes, potentially adding more pressure on the $\mathrm{BC}$ habitats due to increased pollution.

To ensure that benefits such as fishery support from mangrove forests, and to a lesser extent from seagrasses and salt marshes, are better considered in decision-making, countries in the West Africa region have prioritized conservation at a number of different scales. For example, at the regional scale, the Convention for Cooperation in the Protection, Management and Development of the Marine and Coastal Environment of the Atlantic Coast of the West, Central and Southern Africa Region (the Abidjan Convention) provides
Distribution of Seagrasses (UNEP-WCMC and Short 2005), Sea Around Us Global Estuary Database (Alder 2003). Overlaps were determined using ESRI ArcMap 10.3

the overarching legal framework for mangrove use and conservation. The Convention was agreed upon in 1981 based on an action plan developed by the United Nations Environment Program (UNEP) in 1976 to address negative impacts on the region's coastal and marine environment. Building upon the Abidjan Convention, a number of countries have adopted policies and laws to promote mangrove conservation in support of coastal communities, including a range of protected areas throughout the region. The growing recognition of the overall suite of benefits that West Africa's mangrove forests supply to the international community could provide a new source of support to conservation efforts in the region. However, capturing this opportunity will require a minimum level of key 
information and knowledge on the global benefits from the region's mangroves.

\section{Knowledge gaps on the global benefits of West Africa's mangroves}

Relatively little is known about West Africa's BC stocks. Available data sets on West African mangrove coverage reflect different methodologies and are difficult to compare, while information on $\mathrm{C}$ storage is often lacking (Hutchison et al. 2014; Jardine and Siikamäki 2014). Notably, much of the literature that has emerged in the last decade on $\mathrm{BC}$ has omitted the region, despite the presence of significant mangrove forests in many countries (Fig. 2). Furthermore, although the continent is home to $22 \%$ of the world's mangroves, it is the subject of only $7 \%$ of the literature that has attempted to estimate values for the services such as $\mathrm{BC}$ that ecosystems provide (Vegh, Jungwiwattanaporn et al. 2014).

Research over the last 5 years has indicated the potential for a large economic benefit from conservation of $\mathrm{BC}$ in mangrove forests (Siikamäki et al. 2012; Murray et al. 2011). The capability to estimate $\mathrm{BC}$ stocks has grown in recent years, including improved global predictive models of storage in soil and biomass, progress on remote sensing and GIS application in mangroves (Jardine and Siikamäki 2014; Patil et al. 2015; Hutchison et al. 2014). This has led to the development of databases with sufficient relevant data upon which to base estimates of potential payments for BC.

In addition to having a more in-depth and wider coverage of raw $\mathrm{BC}$ data to support $\mathrm{C}$ payment opportunities, a growing body of literature on habitat and $\mathrm{C}$ loss due to conversion pressures has enhanced understanding of the trends and drivers of coastal habitat conversion and $\mathrm{BC}$ loss (Hamilton 2013; Hamilton and Lovette 2015; Polidoro et al. 2010; Barbier and Sathirathai 2004; Barbier and Cox 2003; Valiela et al. 2001). These analyses have led to a similarly-themed growing literature on the valuation of additional benefits from mangrove forests, e.g. supporting fisheries, providing coastal protection, etc. (Kauffman and Bhomia 2014; UNEP 2014; Barbier 2015; Salem and Mercer 2012). For example, a recent study estimated that global mangrove losses have resulted in up to $\$ 42$ billion in economic damages annually due to greenhouse gas emissions losses (UNEP 2014).

As a result of the growing amount of information available on $\mathrm{BC}$ storage capacity, international financing mechanisms are increasingly ready to be deployed to pay for this service as part of the effort to reduce GHG emissions through the creation of C markets (Herr et al. 2015). Furthermore, improved valuation of other benefits provided by mangrove forests and coastal vegetated ecosystems may lead to additional markets to pay for these ecosystem services (PES) - potentially incorporating $\mathrm{BC}$ sequestration and storage.

In terms of markets for $\mathrm{C}$ and accompanying financing mechanisms, $\mathrm{BC}$ has recently become a valid candidate for inclusion under the Reducing Emissions from Deforestation and Forest Degradation (REDD+) market mechanism which prices GHG reductions from forest conservation. Additional international finance mechanisms that could be relevant for BC include several U.N. Framework Convention on Climate Change (UNFCCC) specific funds, bi- and multilateral, as well as national climate funds, among others (Herr et al. 2015). Additionally, novel financing options such as debt-

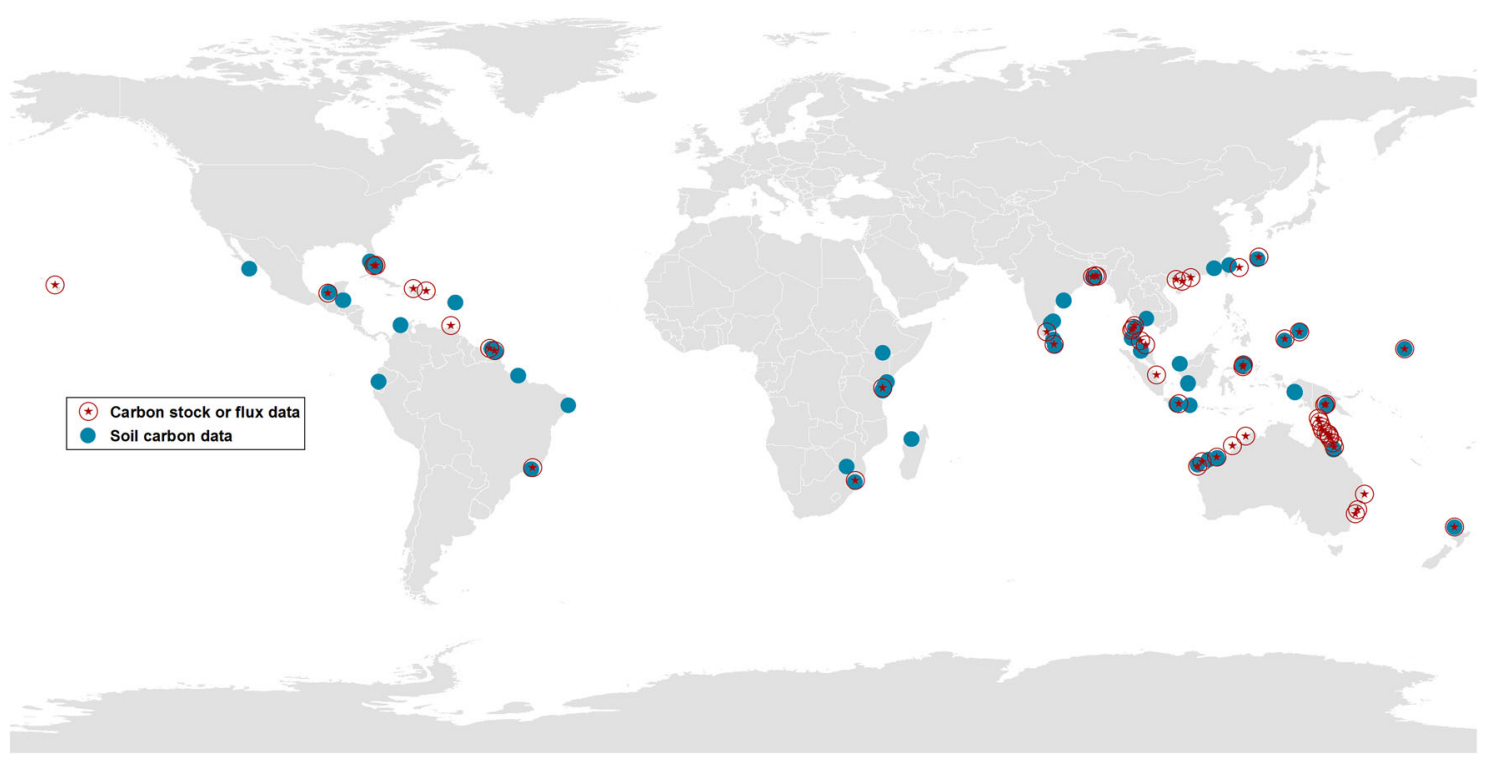

Fig. 2 Global biophysical mangrove data coverage. Note: Red marks

Siikamäki 2014) where soil C data is available from meta-analyses by show locations reported in (Hutchison et al. 2014) where C stock or flux (Chmura et al. 2003; Kristensen et al. 2008; Donato et al. 2011) 
for-nature swaps or payments for biodiversity have also been considered recently for $\mathrm{BC}$ conservation (Ministerio del Ambiente 2015). All of these mechanisms have developed within the last decade and may provide a new opportunity to support West African countries in their goals for conserving mangrove ecosystems, through payments for BC storage. However, there are few examples or significant literature to date on their use for BC, so there is not yet a body of experience from which to refer.

Given the significant benefits of BC storage that mangroves provide to the international community, and its growing willingness to pay for this service, it is surprising that so little is known about West Africa's BC stocks and the steps that communities and countries in the region would need to take in order to capture this opportunity. To help fill that knowledge gap, this study aims to 1) synthesize the current state of information on the size and distribution of BC stocks in West Africa's mangrove forests, 2) estimate the size of payments that could be secured for maintaining BC stocks in mangroves, and 3) discuss the potential for communities and countries to secure BC payments from the international community in order to help implement the region's mangrove conservation policy objectives as well as relevant targets of the Sustainable Development Goals.

\section{Methods}

\section{Biophysical data}

Quantifying mangrove and other BC loss has been difficult due to a lack of comparable time series data sets that use consistent methodology. In terms of the data available for mangrove coverage and $\mathrm{C}$, the project identified the following sources: (Corcoran et al. 2007), (Spalding et al. 2010), (Giri et al. 2011), (Fatoyinbo and Simard 2013)3, (Hutchison et al. 2014), (Jardine and Siikamäki 2014), and Hamilton and Casey 2016.

For seagrasses, datasets by (UNEP-WCMC and Short 2005; Green and Short 2003) have been used to provide coarse data collected over the period 1934-2004. Relative salt marsh abundances within ecoregions is currently available (Hoekstra et al. 2010) and an effort to develop a complete global dataset for salt marsh distribution is still underway at UNEP-WCMC. (Halpern et al. 2008) developed a dataset delineating salt marshes within $1 \mathrm{~km}$ of the shore collected over the period 1975-2007. A global lakes and wetlands database is also available, though the resolution is relatively coarse (30 s) (Lehner and Döll 2004). Finally, a global estuary database is currently available, which may be used as a proxy for salt marsh distribution (Alder 2003).

In this study, the following datasets were used: mangrove coverage data for 1999-2000 from (Fatoyinbo and Simard
2013); salt marsh coverage from (Halpern et al. 2008); and seagrass coverage from (UNEP-WCMC and Short 2005, Green and Short 2003). Coverage is estimated from Green and Short (2003)'s distribution maps, though his work shows a range of seagrass distribution in the region rather than seagrass coverage, therefore, seagrass coverage is likely overestimated. BC areas were estimated for each country (GADM 2015) using ESRI ArcMap 10.3 Spatial Analyst Intersect Tool for vector data and Zonal Statistics as Table Tool for raster data. C stored was calculated as the sum of (1) mean above-ground biomass (Hutchison et al. 2014), (2) mean belowground biomass (Hutchison et al. 2014), and (3) mean soil C (Jardine and Siikamäki 2014), multiplied by coverage of each $\mathrm{BC}$ resource. For mangroves, mean $\mathrm{C}$ content in biomass in (1) and (2) were calculated using biomass-to- $\mathrm{C}$ ratios of 1 -to- 0.46 and 1-to-0.39, respectively, after Howard, Hoyt et al. (2014), page 78 and 90, respectively. For seagrasses and salt marshes, $\mathrm{C}$ per hectare values of 139.2 and $258.7 \mathrm{tC} /$ ha for biomass and top meter of soil carbon were used based on Pendleton et al. (2014). This analysis used a single generalized value for seagrass ecosystems, though ecosystem associated carbon values range multiple orders of magnitude (Fourqurean et al. 2012) being influenced by species (Lavery et al. 2013) and environmental setting (Armitage and Fourqurean 2016; Serrano et al. 2016).

\section{Economic analysis}

Decisions on the use of mangrove forests often do not factor in the economic value of the services provided by these forests when kept intact, such as potential payments for BC (Alongi 2014; Hutchison et al. 2014; Siikamäki et al. 2012; Jardine and Siikamäki 2014). A preliminary net present value (NPV) analysis of the benefits from mangrove conservation in West Africa is performed in this study, considering the potential payments for BC storage in the below- and above-ground biomass, and top meter of soil, as well as the opportunity costs of conservation, i.e. the benefits of conversion to agriculture. Placing a value on the carbon sequestration and storage ecosystem service is straightforward using defensible values for carbon credits or offsets from the literature, or market analyses (Goldstein and Gonzalez 2014).

This analysis calculated the future values of upfront and annual costs and benefits in present value, using 5 and $8 \%$ discount rates and a 20-year time horizon, the midpoint recommended by (UNEP and_CIFOR 2014). Following the methodology of (Pendleton et al. 2014) the NPV analysis includes $\mathrm{BC}$ payments (i.e. $\mathrm{C}$ credit revenue), mangrove conservation project establishment costs, and opportunity costs of conservation (i.e., value per hectare of alternative use), but not $\mathrm{C}$ project transaction costs necessary to access buyers for the credits generated (Galik et al. 2012). The alternative use was assumed to be agriculture, for which returns per hectare 
were collected from (IFAD 2001) and adjusted to current dollar years using the CPI (BLS 2015). Returns reported per hectare averaged \$221 (in 2015\$) with a range of \$38-460. For countries without data, adjacent countries were used to estimate agriculture returns.

The analysis explicitly gives the estimated financial flows from $\mathrm{BC}$ payments, based on avoided $\mathrm{C}$ emissions due to mangrove conservation, two reasonable $\mathrm{C}$ offset prices of $\$ 3$ and 5 per $\mathrm{Mg} \mathrm{CO}_{2} \mathrm{e}$ (Goldstein and Gonzalez 2014) and use the low-end estimate of global mangrove loss rates. Assuming the low-end global conversion rate of $0.7 \%$ per year across the region (Pendleton et al. 2012), we estimate the value of avoided emission reductions from $\mathrm{BC}$ conservation using the two $\mathrm{C}$ prices.

Specifically, at the time of conversion we assumed that all biomass (above and below ground) $\mathrm{C}$ is lost in the year a given area of mangroves is converted. Soil $\mathrm{C}$ is emitted with a halflife of 10 years (Pendleton et al. 2012). Mean C stocks per hectare in the region ranged from 314.4 to $456.1 \mathrm{Mg} \mathrm{C} / \mathrm{ha}$. For comparison, according to measurements on mangroves in the Central Africa region, undisturbed and heavily exploited mangroves store 967 , and 741 tons of $C$ per ha, respectively (Ajonina et al. 2014). We also accounted for continued C sequestration of intact mangroves at a conservative rate of 1.89 tons C / ha / yr (Nellemann and Corcoran 2009) which is lower than the 16.52 tons $\mathrm{C} / \mathrm{ha} / \mathrm{yr}$ reported for intact mangroves in Central Africa (Ajonina et al. 2014). In this study we do not account for methane, and nitrous oxide emissions associated with loss of mangroves.

We use the following model to estimate the financial value of $\mathrm{BC}$ :

$$
\begin{aligned}
& B C \text { Financial Value }{ }_{i}=\sum_{t=0}^{20} \frac{\left(C S_{i t}+A v C E_{i t}\right) \times \text { Price }_{t}}{(1+d)^{t}} \\
& - \text { PAEstab }_{1}-\text { PAMgmt }_{i}-\text { Opp Cost }_{i}
\end{aligned}
$$

Where CS is carbon sequestration in $\mathrm{Mg} \mathrm{C} / \mathrm{ha} / \mathrm{yr}, \mathrm{AvCE}$ is avoided above-, below-ground, and soil (top meter) carbon emissions in $\mathrm{Mg} \mathrm{C} / \mathrm{ha} / \mathrm{yr}$ assuming no net loss of carbon in the business-as-usual scenario, PriceC is carbon market price, PAEstab1 is the one-time cost, in year 1, of establishing protected areas where mangroves are conserved, PAMgmt is the annual cost of managing protected areas where mangroves are conserved, OppCost is the opportunity cost of conservation (i.e. returns from the alternative use of agriculture) and $d$ is the discount rate. All other terms are as defined above. Viable conservation means that the net benefit of conservation is larger than the sum of blue carbon protection cost and the opportunity cost in alternative use (e.g. agriculture). Other significant benefits that intact mangrove forests provide to the region's fisheries e.g. (Barbier 2000; Rönnbäck 1999), or coastal areas in terms of protection services, are not included in our analysis due to the absence of locally estimated values for West Africa.
The analysis uses two sets of protected area establishment and maintenance costs. According to the global analysis by Pendleton et al. (2014) and economic analysis of BC in Belize by (Chang et al. 2015), we assume protection costs (to start a BC project) to be $\$ 232$ / ha (McCrea-Strub et al. 2011) or a lower estimate of $\$ 25 /$ ha based on (Vasconcelos et al. 2014). Ongoing management costs were assumed to be $\$ 1$ (Vasconcelos et al. 2014) based on published region-specific values from Guinea-Bissau, or $\$ 7$ / ha / year (Balmford et al. 2003) representing a higher estimate from the literature. Regarding biophysical data quality, data on $\mathrm{BC}$ loss rates over time, $\mathrm{C}$ burial rates, and $\mathrm{C}$ stock in soil and biomass numbers are the best published scientific estimates. These data are based on global, rather than regional or local estimates and conditions, because data from West Africa is currently very limited e.g. (Hutchison et al. 2014; Jardine and Siikamäki 2014).

\section{Results and discussion}

\section{Size and distribution of West Africa's BC stocks}

According to the datasets analyzed, $\mathrm{BC}$ coverage in the region is dominated by seagrasses (Fig. 3, Table 2). Specifically, Guinea and Guinea-Bissau contain $60 \%$ of the 4.83 million ha of seagrass in the region. Mangrove coverage is more distributed among the countries but the top two mangrove countries, Nigeria and Guinea-Bissau, contain 58\% of the region's 1.97 million ha of mangroves. The 1.17 million ha of salt marshes are even more distributed among countries than mangroves. A breakdown of coverage shows that the 7.98 million ha of $\mathrm{BC}$ are is distributed as $61 \%$ seagrasses, $25 \%$ mangroves, and $15 \%$ salt marshes.

In terms of $\mathrm{C}$ storage, the region contains $1830 \mathrm{Tg}$ of $\mathrm{C}$ in total, of which $854 \mathrm{Tg}(47 \%)$ is found in mangroves in aboveand below-ground biomass and the top meter of soil, $673 \mathrm{Tg}$ (37\%) in seagrasses, and $303 \mathrm{Tg}(17 \%)$ in salt marshes.

A further breakdown of the data on mangrove $\mathrm{C}$ storage presented above provides more detail on storage of biomass $\mathrm{C}$ above and below ground, as well as soil $\mathrm{C}$ (Table 3). Specifically, the data shows that $75 \%$ of the total C stored is located in the top meter of soil, with the remaining $\mathrm{C}$ stored in above ground (19\%) and below ground (6\%) biomass.

\section{Potential value of payments to maintain West Africa's BC stocks}

Under the assumption of continuing mangrove loss in the region, equal to the average global loss rate, the discounted values of avoided $\mathrm{C}$ emissions range between $\$ 0-342$ million, depending on $\mathrm{C}$ price and discount rate used (Table 4). The few countries in the region with limited mangrove resources also have low $\mathrm{BC}$ economic values. Predominantly, however, 
West African countries' $\mathrm{BC}$ values are quite large, even under the assumption of a flat $\mathrm{C}$ price trend, as compared to the prevailing level at the time of writing.

Building from the above values, a preliminary economic analysis of the net present value (NPV) of the C storage benefits from mangrove conservation in West Africa is provided below, considering the potential payments for $\mathrm{BC}$, as well as the opportunity costs of conservation, i.e. the benefits of conversion to agriculture. The additional benefits that intact mangrove forests provide are not included due to lack of data, such as supporting the region's fisheries. Hence, this analysis should be considered conservative, and indicative. However, even without including values for the benefits of intact mangroves in addition to $\mathrm{BC}$ storage and sequestration, the analysis suggests that conservation of mangroves is economically viable when factoring in net benefits (returns from the alternative use of land in agriculture) as high as $\$ 460$ / ha, with an average of $\$ 221$ / ha. Therefore, just on the basis of the potential payments for BC, most countries in West Africa can achieve a net economic benefit from mangrove conservation. The top 8 mangrove countries by mangrove area, for instance, can realize net benefits of millions of USD even under our conservative assumptions of $C$ prices (Table 5). Together with payments for other services provided, mangrove conservation from an economic perspective in West African nations can be financially viable.

\section{Securing payments to maintain West Africa's BC stocks}

\section{Regional development policy context for mangrove use}

Current regional economic growth policies were established in 2010 by the ECOWAS Commission, ${ }^{1}$ which set a future economic trend for the region in its "Vision for 2020" paper (ECOWAS-CEDEAO 2010). Sustainable development and environmental preservation are two key pillars of the vision statement of ECOWAS, and form guiding principles for national policies related to the use of mangroves throughout the region. At the national level, development and economic growth policies for West African countries are described in Poverty Reduction Strategy Papers (PRSPs). Environmental policies within the PRSPs typically focus on 1) improved biodiversity, 2) ecological restoration of natural communities, and 3) development of protected areas and wetlands. Moreover, PRSPs in countries in West Africa refer to unsustainable natural resource management decisions as key reasons for environmental degradation and set goals to better align their environmental policies with sustainable management principles.

\footnotetext{
${ }^{1}$ Members not studied in this report include Cape Verde, Mali, and Niger
}

\section{Regional policy framework for mangrove use}

Similarly to regional development policies, national Ministries of the Environment in the region have defined their policy goal as "to ensure environmental protection and the conservation of natural resources for sustainable development" (Nigeria 1999). Using Nigeria-the largest mangrove country in the region-as an example, and crosschecking national policies of other countries in the region to see whether they match policies of Nigeria, key components in national environmental policies can be identified as:

1) Environmental quality must not compromise good health and well being

2) Sustainable resource use

3) Restoration and maintenance of biodiversity

4) Linking of environmental, social, and economic development goals

5) Encouraging individual and community participation in environmental improvement initiatives

6) Raising public awareness and engendering a national culture of environmental preservation

7) Building partnership among relevant stakeholders including government at all levels, international institutions and governments, non-governmental agencies and communities

These components of environmental policy are fairly consistent among countries in West Africa, and the regional need to better manage the use of mangrove forests stemming from this policy consistency has been indicated in international workshops (USAID et al. 2014) and reports (Ajonina et al. 2014) on BC as well as ongoing research in the region.

\section{Opportunities, constraints, issues of uncertainty}

Recent research has identified the opportunities, constraints, and issues of uncertainty associated with payments for maintaining BC stocks (Barnes 2014). Indeed, there are growing opportunities to receive payments for $\mathrm{BC}$, mostly in mangroves, building off of improved measurement, reporting, and verification. The ability to effectively measure, report and verify reductions in emissions is a requirement for effective BC policies (Ullman et al. 2013). This may be straightforward for living tissue that can burn or quickly decompose, though quantitatively estimating $\mathrm{CO}_{2}$ emissions from belowground biomass and soil fractions is likely to be highly variable and still exists as a primary hurdle in blue carbon understanding.

Despite these hurdles, successful recent BC project demonstration sites, such as Mikoko Pamoja in Kenya, are paving the path to more complete and geographically widespread adoption of payments for conservation. However, for every 
Table 2 West Africa's BC stocks: area of habitats and C stored

\begin{tabular}{|c|c|c|c|c|c|c|c|c|}
\hline \multirow[b]{2}{*}{ Country } & \multicolumn{4}{|l|}{ Area (ha) } & \multicolumn{3}{|l|}{ C stored $(\mathrm{Tg})$} & \multirow[b]{2}{*}{ Total } \\
\hline & Mangroves & Seagrasses & Salt marshes & Total & Mangroves & Seagrasses & Salt marshes & \\
\hline Angola & 15,400 & 60,050 & 190,900 & 266,350 & 7 & 8 & 49 & 64 \\
\hline Benin & 1800 & 135,808 & 11,100 & 148,708 & 1 & 19 & 3 & 23 \\
\hline Cameroon & 148,300 & - & 56,400 & 204,700 & 65 & - & 15 & 80 \\
\hline Congo & 1500 & - & 15,500 & 17,000 & 1 & - & 4 & 5 \\
\hline Côte d'Ivoire & 3200 & - & 50,100 & 53,300 & 1 & - & 13 & 14 \\
\hline D.R. Congo & 18,300 & - & 5400 & 23,700 & 6 & - & 1 & 7 \\
\hline Eq. Guinea & 18,100 & - & 43,400 & 61,500 & 8 & - & 11 & 19 \\
\hline Gabon & 145,700 & - & 103,200 & 248,900 & 66 & - & 27 & 93 \\
\hline Gambia & 51,911 & - & 8800 & 60,711 & 22 & - & 2 & 25 \\
\hline Ghana & 7600 & 271,858 & 53,200 & 332,658 & 3 & 38 & 14 & 55 \\
\hline Guinea & 188,900 & $1,301,092$ & 68,700 & $1,558,692$ & 82 & 181 & 18 & 281 \\
\hline Guinea-Bissau & 280,600 & $1,560,911$ & 152,700 & $1,994,211$ & 116 & 217 & 40 & 373 \\
\hline Liberia & 18,900 & - & 53,000 & 71,900 & 8 & - & 14 & 22 \\
\hline Mauritania & 40 & - & 112,800 & 112,840 & 0 & - & 29 & 29 \\
\hline Nigeria & 857,300 & 884,495 & 88,800 & 1830,595 & 377 & 123 & 23 & 523 \\
\hline São Tomé and Príncipe & ND & - & 20,600 & 20,600 & ND & - & 5 & 5 \\
\hline Senegal & 120,000 & 151,982 & 55,600 & 327,582 & 50 & 21 & 14 & 85 \\
\hline Sierra Leone & 95,500 & 447,248 & 77,600 & 620,348 & 41 & 62 & 20 & 123 \\
\hline Togo & 200 & 18,804 & 5200 & 24,204 & 0 & 3 & 1 & 4 \\
\hline West Africa Grand Total & $1,973,251$ & $4,832,247$ & $1,173,000$ & $7,978,498$ & 854 & 673 & 303 & 1830 \\
\hline
\end{tabular}

Carbon stored in mangroves includes above- and below-ground biomass and the top meter of soil

Sources: (Fatoyinbo and Simard 2013; Green and Short 2003; Halpern et al. 2008; Pendleton et al. 2014)

opportunity regarding payments for $\mathrm{BC}$ conservation, there are just as many constraints. With protected area establishment costs as high as over $\$ 230$ per hectare together with ambiguity around a clear path forward for the acceptance of $\mathrm{BC}$ into $\mathrm{C}$ offset markets, such payments often cannot be viewed as a stand-alone solution to finance mangrove conservation. Despite these constraints, payments for $\mathrm{BC}$ have been advancing in a number of developing countries.

An important issue to keep in mind when developing blue carbon projects is additionality. If a project is started before payments for the avoided carbon emissions are received through a carbon market transaction, for instance, the additionality criterion might be compromised. If a blue carbon market were to form, these would essentially become environmental market products that could help mangrove conservation project developers cover the cost of protected are establishment and management. These credits, then could be used as marketable "offsets" that buyers could use to help meet their regulatory or voluntary GHG goals.

If other ecosystem service payments, other than carbon, could be paid to mangrove conservation project developers the issue of credit stacking could arise. Stacking refers to receiving multiple environmental payments to finance the mangrove conservation project. Clearly, multiple payments can increase revenues and thus increase the attractiveness of the conservation project. However, the use of stacked credits also introduces the possibility that some of the stacked credits might be "non-additional" in that they do not produce incremental pollution reductions and thus are suspect for use in offsetting the offset buyer's GHG pollution, in the case of carbon.

West African countries or communities interested in securing payments for $\mathrm{BC}$ now have access to multiple guidance documents from project planning and delivery to finance. Recent and detailed guidance exists for planning a $\mathrm{BC}$ project from concept development to regulatory compliance (UNEP_and_CIFOR 2014) as well as for fast-tracking national implementation of $\mathrm{BC}$ activities in developing countries.

Perhaps the most ambiguous yet crucial potential impediment to the success of a $\mathrm{BC}$ projects is land tenure. The overlapping of marine and terrestrial resources in $\mathrm{BC}$ itself creates tenure ambiguities making resource management and coastal decision making challenging. In addition, land tenure issues specific to REDD+ (i.e. forest tenure and $\mathrm{C}$ rights) as described in (Galik and Jagger 2015) pose a risk to BC project development and management. That is partly because of differences in formal or de facto and informal or de jure land tenure as these relate to the right of alienation of land with 
Table 3 West African BC stocks in mangrove forests

\begin{tabular}{|c|c|c|c|c|c|c|c|c|c|}
\hline \multirow[b]{2}{*}{ Country name } & \multirow[b]{2}{*}{$\begin{array}{l}\text { Mangrove } \\
\text { area (ha) }\end{array}$} & \multicolumn{4}{|c|}{ Mean C Storage $(\mathrm{Mg} / \mathrm{ha})$} & \multicolumn{4}{|c|}{ Total C Storage (Tg) } \\
\hline & & $\begin{array}{l}\text { Top meter } \\
\text { of soil }\end{array}$ & $\begin{array}{l}\text { Above ground } \\
\text { biomass }\end{array}$ & $\begin{array}{l}\text { Below ground } \\
\text { biomass }\end{array}$ & $\begin{array}{l}\text { All } \\
\text { stocks }\end{array}$ & $\begin{array}{l}\text { Top meter } \\
\text { of soil }\end{array}$ & $\begin{array}{l}\text { Above ground } \\
\text { biomass }\end{array}$ & $\begin{array}{l}\text { Below ground } \\
\text { biomass }\end{array}$ & $\begin{array}{l}\text { All } \\
\text { stocks }\end{array}$ \\
\hline Angola & 15,400 & 354.4 & 53.0 & 17.6 & 425.0 & 5.5 & 0.8 & 0.3 & 6.5 \\
\hline Benin & 1800 & 317.1 & 72.3 & 23.1 & 412.5 & 0.6 & 0.1 & 0.0 & 0.7 \\
\hline Cameroon & 148,300 & 324.2 & 86.9 & 29.5 & 440.5 & 48.1 & 12.9 & 4.4 & 65.3 \\
\hline Congo & 1500 & 321.4 & 54.7 & 17.1 & 393.2 & 0.5 & 0.1 & 0.0 & 0.6 \\
\hline Côte d'Ivoire & 3200 & 321.6 & 80.1 & 24.3 & 426.0 & 1.0 & 0.3 & 0.1 & 1.4 \\
\hline D.R. Congo & 18,300 & 321.6 & ND & $\mathrm{ND}$ & 321.6 & 5.9 & ND & ND & 5.9 \\
\hline Eq. Guinea & 18,100 & 340.8 & 75.2 & 24.4 & 440.4 & 6.2 & 1.4 & 0.4 & 8.0 \\
\hline Gabon & 145,700 & 368.3 & 66.9 & 20.9 & 456.1 & 53.7 & 9.7 & 3.0 & 66.5 \\
\hline Gambia & 51,911 & 343.4 & 65.2 & 20.2 & 428.8 & 17.8 & 3.4 & 1.0 & 22.3 \\
\hline Ghana & 7600 & 320.2 & 75.1 & 22.3 & 417.6 & 2.4 & 0.6 & 0.2 & 3.2 \\
\hline Guinea & 188,900 & 317.5 & 86.4 & 29.3 & 433.1 & 60.0 & 16.3 & 5.5 & 81.8 \\
\hline Guinea-Bissau & 280,600 & 316.3 & 73.4 & 23.7 & 413.4 & 88.8 & 20.6 & 6.7 & 116.0 \\
\hline Liberia & 18,900 & 322.2 & 95.5 & 28.6 & 446.4 & 6.1 & 1.8 & 0.5 & 8.4 \\
\hline Mauritania & 40 & 333.5 & ND & ND & 333.5 & 0.0 & ND & ND & 0.0 \\
\hline Nigeria & 857,300 & 322.0 & 87.8 & 29.9 & 439.7 & 276.0 & 75.3 & 25.6 & 376.9 \\
\hline $\begin{array}{l}\text { São Tomé and } \\
\text { Príncipe }\end{array}$ & ND & ND & ND & ND & ND & ND & ND & ND & ND \\
\hline Senegal & 120,000 & 328.2 & 64.0 & 22.0 & 414.2 & 39.4 & 7.7 & 2.6 & 49.7 \\
\hline Sierra Leone & 95,500 & 320.0 & 81.1 & 26.9 & 428.1 & 30.6 & 7.7 & 2.6 & 40.9 \\
\hline Togo & 200 & 314.4 & ND & ND & 314.4 & 0.1 & ND & ND & 0.1 \\
\hline $\begin{array}{l}\text { West Africa } \\
\text { Grand Total }\end{array}$ & $1,973,251$ & & & & & 642.4 & 158.6 & 53.1 & 854.1 \\
\hline
\end{tabular}

Sources: (Fatoyinbo and Simard 2013; Jardine and Siikamäki 2014; Hutchison et al. 2014)

$\mathrm{BC}$ resource. But more than that, under REDD+ payments, changes in land tenure might result from the contractual agreement especially regarding $\mathrm{C}$ rights that are assigned at the development of the $\mathrm{BC}$ project, leading to the argument of land grabbing and the possibility of the exclusion of certain groups from accessing their traditional areas. These issues regarding land tenure must be appropriately resolved based on the latest scientific advances and recommendations including recommendations for and lessons learned from operationalizing REDD+ (Olander et al. 2012).

Along with the development of $\mathrm{BC}$ projects, national climate mitigation efforts might also consider incorporating $\mathrm{BC}$ activities into their programs by following the steps outlined by (Herr and Pidgeon 2015). The newly-released VCS methodology for BC restoration (VCS 2015) provide guidance as to the use of the methodology to secure payments for $\mathrm{BC}$. To finance these activities and projects, multiple current $\mathrm{BC}$ relevant financing options are described in the literature (Herr et al. 2015). Those interested might also look at the example and leadership of Guinea-Bissau in securing BC payments.

Other $\mathrm{BC}$ demonstration sites for conservation and restoration projects have begun to emerge around the globe, demonstrating the use of a wide range of various financing mechanisms available to project developers, or countries with $\mathrm{BC}$ resources they set out to protect (Ministerio del Ambiente 2015; Herr et al. 2015). The use of $C$ finance in all of its various forms to pay for maintenance of the $\mathrm{BC}$ stocks in mangroves is nascent, and the above sample of projects are all small steps compared to the scale at which mangrove conversion and sequestration capacity globally.

\section{Potential viability of BC payments}

Regardless the specific market, private $\mathrm{C}$ finance offers a potentially viable source of payments for BC. Economic analyses have estimated that large scale conservation of the $\mathrm{BC}$ stocks in mangroves is feasible, even at relatively low $\mathrm{C}$ prices such as $\$ 10$ per ton of $\mathrm{C}$ dioxide equivalent, while also considering opportunity costs (i.e. the revenue streams from economic activities on converted mangrove habitats) (Siikamäki et al. 2012; Murray et al. 2011). To put $\$ 10$ per ton into perspective, at the end of $2015 \mathrm{C}$ was trading at $\$ 12.70, \$ 8.45$, and $\$ 5.50$ per metric ton on the California compliance $\mathrm{C}$ market, European Union Emissions Trading Scheme, and Regional Greenhouse Gas Initiative markets, respectively. 
Table 4 BC financial value for West African countries

\begin{tabular}{|c|c|c|c|c|c|c|}
\hline \multirow[t]{3}{*}{ Country name } & \multirow[t]{3}{*}{ Mangrove area (ha) } & \multirow[t]{3}{*}{ Avoided C emissions (20 yr, Mg) } & \multicolumn{4}{|c|}{ Discounted value of avoided C emissions (million USD) } \\
\hline & & & \multicolumn{2}{|l|}{$5 \%$} & \multicolumn{2}{|l|}{$8 \%$} \\
\hline & & & $\$ 3 / \mathrm{tCO} 2 \mathrm{e}$ & $\$ 5 / \mathrm{tCO} 2 \mathrm{e}$ & $\$ 3 / \mathrm{tCO} 2 \mathrm{e}$ & $\$ 5 / \mathrm{tCO} 2 \mathrm{e}$ \\
\hline Angola & 15,400 & 526,814 & $\$ 3.2$ & $\$ 5.4$ & $\$ 2.4$ & $\$ 4.0$ \\
\hline Benin & 1800 & 62,695 & $\$ 0.4$ & $\$ 0.7$ & $\$ 0.3$ & $\$ 0.5$ \\
\hline Cameroon & 148,300 & $5,642,486$ & $\$ 35.5$ & $\$ 59.1$ & $\$ 26.6$ & $\$ 44.3$ \\
\hline Congo & 1500 & 48,088 & $\$ 0.3$ & $\$ 0.5$ & $\$ 0.2$ & $\$ 0.4$ \\
\hline Côte d'Ivoire & 3200 & 116,214 & $\$ 0.7$ & $\$ 1.2$ & $\$ 0.5$ & $\$ 0.9$ \\
\hline Democratic Republic of the Congo & 18,300 & 415,856 & $\$ 2.4$ & $\$ 4.1$ & $\$ 1.7$ & $\$ 2.9$ \\
\hline Equatorial Guinea & 18,100 & 670,312 & $\$ 4.2$ & $\$ 7.0$ & $\$ 3.1$ & $\$ 5.2$ \\
\hline Gabon & 145,700 & $5,452,036$ & $\$ 33.7$ & $\$ 56.2$ & $\$ 25.0$ & $\$ 41.6$ \\
\hline Gambia & 51,911 & $1,835,923$ & $\$ 11.4$ & $\$ 19.0$ & $\$ 8.4$ & $\$ 14.1$ \\
\hline Ghana & 7600 & 268,337 & $\$ 1.7$ & $\$ 2.8$ & $\$ 1.2$ & $\$ 2.1$ \\
\hline Guinea & 188,900 & $7,084,009$ & $\$ 44.6$ & $\$ 74.3$ & $\$ 33.4$ & $\$ 55.6$ \\
\hline Guinea-Bissau & 280,600 & $9,819,840$ & $\$ 61.3$ & $\$ 102.2$ & $\$ 45.7$ & $\$ 76.2$ \\
\hline Liberia & 18,900 & 735,654 & $\$ 4.6$ & $\$ 7.7$ & $\$ 3.5$ & $\$ 5.8$ \\
\hline Mauritania & 40 & 942 & $\$ 0.0$ & $\$ 0.0$ & $\$ 0.0$ & $\$ 0.0$ \\
\hline Nigeria & 857,300 & $32,642,801$ & $\$ 205.3$ & $\$ 342.2$ & $\$ 153.8$ & $\$ 256.3$ \\
\hline São Tomé and Príncipe & ND & N/A & N/A & N/A & $\mathrm{N} / \mathrm{A}$ & N/A \\
\hline Senegal & 120,000 & $4,124,332$ & $\$ 25.6$ & $\$ 42.7$ & $\$ 19.0$ & $\$ 31.7$ \\
\hline Sierra Leone & 95,500 & $3,502,329$ & $\$ 22.0$ & $\$ 36.6$ & $\$ 16.4$ & $\$ 27.4$ \\
\hline Togo & 200 & 4444 & $\$ 0.0$ & $\$ 0.0$ & $\$ 0.0$ & $\$ 0.0$ \\
\hline West Africa Grand Total & $1,973,251$ & $72,953,113$ & & & & \\
\hline
\end{tabular}

Avoided emissions were calculated under the assumption of $0.7 \%$ annual loss (Pendleton et al. 2012)

The voluntary markets have been trading $\mathrm{C}$ at a lower marketaverage price of $\$ 4.90$, with REDD+ credits applicable to $\mathrm{BC}$ averaging $\$ 4.20$ according to 2013 data from Forest Trends (Goldstein and Gonzalez 2014). So, while $\$ 10$ per tonne is achievable on the compliance market, the voluntary market, where BC credits could more likely be traded, will have to increase their prices considerably. This does not mean that the $\mathrm{BC}$ projects are not viable at the lower price range of $\mathrm{C}$, but there must be other revenue streams associated with the project (e.g. tourist revenues) to cover some of the higher costs of the project, such as large-scale restoration activities.

In general, $\mathrm{C}$ market prices and trading volumes have fluctuated over the past few years. Experts, however, are optimistic about future $\mathrm{C}$ market developments both in terms of volume and prices (Goldstein and Gonzalez 2014). Regulated carbon markets are driven by an arbitrary cap on emissions and the marginal cost of carbon offset alternatives, for example, from the power sector.

The price of $\mathrm{C}$ may also be bolstered by recent global political events, such as the United Nations Conference on Climate Change (COP) 21 in Paris in December 2015. This COP meeting sent a strong signal to the global environmental community that $\mathrm{C}$ pollution is to be reduced such that the predicted global average temperature increase remains "well below" 2 degrees Celsius above pre-industrial levels (United Nations 2015b). The extent to which $\mathrm{BC}$ will be able to play a role in achieving this target will depend on the development of market-specific methodologies to credibly measure, report, and verify (MRV) greenhouse gas emissions from BC ecosystems. Moving forward, the two biggest uncertainties for $\mathrm{BC}$ projects to access $\mathrm{C}$ markets at scale remain (1) the uncertainty of whether policies will be enacted to create $\mathrm{C}$ markets of global scale and breadth, (2) whether such markets will accept BC conservation or restoration as credible activities, and (3) whether the influx of a large quantity of new offsets will "flood" the market, increase supply way above demand, resulting in a large drop in market price.

With the finalization of the Verified C Standard (VCS) Tidal Wetland Restoration protocol (V-C-S 2015), the entry of payments for $\mathrm{BC}$ into voluntary $\mathrm{C}$ markets is a real possibility and a significant opportunity to scale up financing. While voluntary or compliance $\mathrm{C}$ markets are only one way to generate payments for $\mathrm{BC}$ projects and activities, they offer positive aspect for developing financing capacity if the disparate regional $\mathrm{C}$ markets, including the compliance-driven E.U. and South Korea Emissions Trading Schemes, the California- 
Table 5 Net benefit of BC conservation in West Africa's mangroves under low and high conservation cost scenarios

\begin{tabular}{|c|c|c|c|c|}
\hline \multirow[t]{3}{*}{ Country name } & \multicolumn{4}{|c|}{ Net financial benefit of mangrove conservation (million USD) } \\
\hline & \multicolumn{2}{|c|}{$\$ 3 / \mathrm{tCO} 2 \mathrm{e}$} & \multicolumn{2}{|c|}{$\$ 5 / \mathrm{tCO} 2 \mathrm{e}$} \\
\hline & $5 \%$ & $8 \%$ & $5 \%$ & $8 \%$ \\
\hline \multirow[t]{2}{*}{ Angola } & $\$ 2.8$ & $\$ 2.0$ & $\$ 4.9$ & $\$ 3.6$ \\
\hline & $\$ 2.4$ & $\$ 1.8$ & $\$ 4.6$ & $\$ 3.4$ \\
\hline \multirow[t]{2}{*}{ Benin } & $\$(0.2)$ & $\$(0.1)$ & $\$ 0.0$ & $\$ 0.0$ \\
\hline & $\$(0.3)$ & $\$(0.2)$ & $\$(0.0)$ & $\$ 0.0$ \\
\hline \multirow[t]{2}{*}{ Cameroon } & $\$(12.6)$ & $\$(7.7)$ & $\$ 11.1$ & $\$ 10.0$ \\
\hline & $\$(15.7)$ & $\$(10.2)$ & $\$ 7.9$ & $\$ 7.5$ \\
\hline \multirow[t]{2}{*}{ Congo } & $\$ 0.3$ & $\$ 0.2$ & $\$ 0.4$ & $\$ 0.3$ \\
\hline & $\$ 0.2$ & $\$ 0.2$ & $\$ 0.4$ & $\$ 0.3$ \\
\hline \multirow[t]{2}{*}{ Côte d'Ivoire } & $\$ 0.0$ & $\$ 0.1$ & $\$ 0.5$ & $\$ 0.4$ \\
\hline & $\$(0.0)$ & $\$ 0.0$ & $\$ 0.5$ & $\$ 0.4$ \\
\hline \multirow[t]{2}{*}{ Democratic Republic of the Congo } & $\$ 1.9$ & $\$ 1.3$ & $\$ 3.5$ & $\$ 2.5$ \\
\hline & $\$ 1.5$ & $\$ 1.0$ & $\$ 3.1$ & $\$ 2.2$ \\
\hline \multirow[t]{2}{*}{ Equatorial Guinea } & $\$ 1.0$ & $\$ 0.8$ & $\$ 3.8$ & $\$ 2.9$ \\
\hline & $\$ 0.6$ & $\$ 0.5$ & $\$ 3.4$ & $\$ 2.6$ \\
\hline \multirow[t]{2}{*}{ Gabon } & $\$ 29.2$ & $\$ 21.7$ & $\$ 51.7$ & $\$ 38.4$ \\
\hline & $\$ 26.1$ & $\$ 19.3$ & $\$ 48.6$ & $\$ 36.0$ \\
\hline \multirow[t]{2}{*}{ Gambia } & $\$ 0.9$ & $\$ 0.9$ & $\$ 8.4$ & $\$ 6.6$ \\
\hline & $\$(0.3)$ & $\$ 0.1$ & $\$ 7.3$ & $\$ 5.7$ \\
\hline \multirow[t]{2}{*}{ Ghana } & $\$(0.1)$ & $\$(0.0)$ & $\$ 1.0$ & $\$ 0.8$ \\
\hline & $\$(0.3)$ & $\$(0.1)$ & $\$ 0.9$ & $\$ 0.7$ \\
\hline \multirow[t]{2}{*}{ Guinea } & $\$ 12.4$ & $\$ 10.4$ & $\$ 42.1$ & $\$ 32.6$ \\
\hline & $\$ 8.3$ & $\$ 7.2$ & $\$ 38.0$ & $\$ 29.5$ \\
\hline \multirow[t]{2}{*}{ Guinea-Bissau } & $\$ 13.5$ & $\$ 11.6$ & $\$ 54.4$ & $\$ 42.1$ \\
\hline & $\$ 7.5$ & $\$ 6.9$ & $\$ 48.4$ & $\$ 37.4$ \\
\hline \multirow[t]{2}{*}{ Liberia } & $\$ 1.4$ & $\$ 1.2$ & $\$ 4.5$ & $\$ 3.5$ \\
\hline & $\$ 1.0$ & $\$ 0.9$ & $\$ 4.1$ & $\$ 3.2$ \\
\hline \multirow[t]{2}{*}{ Mauritania } & $\$ 0.0$ & $\$ 0.0$ & $\$ 0.0$ & $\$ 0.0$ \\
\hline & $\$(0.0)$ & $\$(0.0)$ & $\$ 0.0$ & $\$ 0.0$ \\
\hline \multirow[t]{2}{*}{ Nigeria } & $\$ 72.6$ & $\$ 59.0$ & $\$ 209.5$ & $\$ 161.5$ \\
\hline & $\$ 54.2$ & $\$ 44.7$ & \$ 191.1 & $\$ 147.3$ \\
\hline \multirow[t]{2}{*}{ São Tomé and Príncipe } & N/A & N/A & $\mathrm{N} / \mathrm{A}$ & N/A \\
\hline & N/A & N/A & $\mathrm{N} / \mathrm{A}$ & N/A \\
\hline \multirow[t]{2}{*}{ Senegal } & $\$ 10.2$ & $\$ 8.0$ & $\$ 27.3$ & $\$ 20.7$ \\
\hline & $\$ 7.7$ & $\$ 6.0$ & $\$ 24.7$ & $\$ 18.7$ \\
\hline \multirow[t]{2}{*}{ Sierra Leone } & $\$ 5.7$ & $\$ 4.8$ & $\$ 20.3$ & $\$ 15.7$ \\
\hline & $\$ 3.7$ & $\$ 3.2$ & $\$ 18.3$ & $\$ 14.2$ \\
\hline \multirow[t]{2}{*}{ Togo } & $\$(0.0)$ & $\$(0.0)$ & $\$(0.0)$ & $\$(0.0)$ \\
\hline & $\$(0.0)$ & $\$(0.0)$ & $\$(0.0)$ & $\$(0.0)$ \\
\hline
\end{tabular}

For each country the top row represents results for a low conservation cost scenario, while the bottom row represents results for a high conservation cost scenario as described in the methodology above. Discount rates of 5 and $8 \%$, and $\mathrm{C}$ prices of $\$ 3$ and 5 were used in the analysis to provide results under alternative scenarios

Quebec market, the Regional Greenhouse Gas Initiative; and the voluntary and Climate Action Reserve (CAR), VCS, and others, that are currently developing and operating independently, become linked or integrated in the future.
From the types of $\mathrm{C}$ markets, the voluntary markets would likely be more adaptable to the West Africa region, as opposed to a regulated market or compliance scheme requiring a national, regional or international cap on greenhouse gas emissions. 
Voluntary markets can serve as a testing ground for new procedures, methodologies and technologies that may later be included in the introductory of a regulatory scheme, as projects can be implemented with fewer transaction costs than in the compliance markets. At the same time, voluntary markets would have lower $\mathrm{C}$ prices and trading volumes than regulated markets.

Additionally, 'debt-for-nature' swaps may be another mechanism to finance mangrove conservation, whereby a portion of a country's foreign debt is forgiven in exchange for local investments in environmental conservation. For example, in the Seychelles, the country has completed a debt-swap to redirect a portion of their current debt payments from external creditors to fund marine conservation activities such as marine protected areas.

\section{Summary and conclusions}

West African communities and countries could capture global funding for mangrove conservation, in payment for the $\mathrm{C}$ sequestration function of these ecosystems. While mangroves provide many well-documented benefits for communities along West Africa's coast, for example as protection from flooding and nursery areas for commercially important fish stocks, they also provide $\mathrm{C}$ storage for which the international community may be willing to pay. Hence if communities can capitalize the global benefits to fund the costs of local conservation and benefits, it may be an additional pathway to poverty reduction in some cases.

With the Paris COP in 2015, a number of opportunities have emerged or are continuing that may provide useful sources of capital to finance conservation of West African mangroves, including cap-and-trade under the UNFCCC, large non-UNFCCC dependent cap-and-trade schemes such as the European Union Emissions Trading System (ETS), large national schemes, subnational schemes, or the voluntary $\mathrm{C}$ market.

Over 93\% of West Africa's estimated area of mangroves can be found in seven countries: Nigeria, Guinea-Bissau, Guinea, Cameroon, Gabon, Sierra Leone, and Senegal. These countries represent the top BC investment opportunities for West Africa. From these seven countries, initial opportunities might be identified based on consideration of political, governance, technical, social, or environmental risks. For these opportunities to materialize, important steps need to be taken regionally and nationally. At the regional level, a support program and information clearinghouse could be established to assist countries to undertake the work needed to capture this opportunity. This assistance could include socio-economic assessments and monitoring of mangrove condition, facilitation of enhanced regional cooperation, or the development of pathways for West African BC projects to access international finance.

At the national level, efforts to conserve mangroves are often fragmented. From a juridical-administrative point of view, the mangrove forests are a composite and unstable area, difficult to define. Despite these difficulties, efforts should continue in building on national mapping activities to focus on identifying key areas that will be crucial for climate change mitigation and adaptation. These efforts could lead to maps that help prioritize areas that are most important for coastal protection, fisheries production, climate change mitigation and adaptation. Key additional aspects of mangrove conservation are sustainable management on the landscape scale, increased community awareness and benefit-sharing.

As individual $\mathrm{BC}$ projects are a developed, it will be crucial to determine the motivating factor in order to establish the project expectations, whether it is to obtain sustainable financing, national report strategies or a tool to better inform and motivate mangrove conservation. It cannot be overstated, that it is far better to protect mangroves now than have to restore or rehabilitate later. In short, $\mathrm{BC}$ is possible and would be helpful within West Africa, both to continue to promote the conservation of mangroves, but also in helping to provide a source of innovative financing, while bringing to light the wealth contained with these coastal ecosystems and their values economically, ecologically as well as culturally - at a community and regional level as well as at a global level.

Acknowledgements Personal communication [John Poulsen (Duke University) and Lola Fatoyinbo (NASA), Aurelie Shapiro (WWF), Carl Trettin (USFS)] Ben Halpern (University of California, Santa Barbara), Sunny Jardine (University of Delaware), Stuart Hamilton (Salisbury University), Mark Spalding (The Nature Conservancy).

Funding This work was supported by GRID-Arendal, a center collaborating with the United Nations Environment Programme (UNEP).

Open Access This article is licensed under a Creative Commons Attribution 4.0 International License, which permits use, sharing, adaptation, distribution and reproduction in any medium or format, as long as you give appropriate credit to the original author(s) and the source, provide a link to the Creative Commons licence, and indicate if changes were made. The images or other third party material in this article are included in the article's Creative Commons licence, unless indicated otherwise in a credit line to the material. If material is not included in the article's Creative Commons licence and your intended use is not permitted by statutory regulation or exceeds the permitted use, you will need to obtain permission directly from the copyright holder. To view a copy of this licence, visit http://creativecommons.org/licenses/by/4.0/.

\section{References}

Ajonina, G. , J. G. Kairo, G. Grimsditch, T. Sembres, G. Chuyong, D. E. Mibog, A. Nyambane, and C. FitzGerald. 2014. Carbon pools and multiple benefits of mangroves in Central Africa: assessment for REDD+. UNEP

Alder J (2003) Putting the coast in the "sea around us". The Sea Around Us Newsletter 15:1-2

Alongi DM (2014) Carbon cycling and storage in mangrove forests. Annu Rev Mar Sci 6:195-219 
Armitage AR, Fourqurean JW (2016) Carbon storage in seagrass soils: long-term nutrient history exceeds the effects of near-term nutrient enrichment. Biogeosciences 13(1):313-321

Balmford A, Gaston KJ, Blyth S, James A, Kapos V (2003) Global variation in terrestrial conservation costs, conservation benefits, and unmet conservation needs. Proc Natl Acad Sci 100(3):1046-1050

Barbier EB (2000) Valuing the environment as input: review of applications to mangrove-fishery linkages. Ecol Econ 35(1):47-61

Barbier EB (2015) Valuing the storm protection service of estuarine and coastal ecosystems. Ecosystem Services 11:32-38

Barbier EB, Cox M (2003) Does economic development Lead to mangrove loss? A cross-country analysis. Contemp Econ Policy 21(4):418-432

Barbier E, and Sathirathai S. (2004). Shrimp farming and mangrove loss in Thailand: Edward Elgar Publishing

Barbier EB, Hacker SD, Kennedy C, Koch EW, Stier AC, Silliman BR (2011) The value of estuarine and coastal ecosystem services. Ecol Monogr 81:169-193

Barnes N (2014) Developing a framework for blue carbon payments. Duke University, M.S. M.S.

BLS. 2015. CPI Inflation Calculator. http://www.bls.gov/data/inflation calculator.htm

Chang SW, Green AA, Kelley EA, Murray BC, Silliman BR (2015) A preliminary assessment of the blue carbon capacity of Belizean mangroves with ecological, economic, and policy perspectives. Duke University, Durham

Chmura GL, Anisfeld SC, Cahoon DR, Lynch JC (2003) Global carbon sequestration in tidal, saline wetland soils. Glob Biogeochem Cycles 17(4)

Corcoran E, Ravilious C, Skuja M (eds) (2007) Mangroves of western and Central Africa. Report produced for UNEP-DEPI under the UNEP biodiversity related projects in Africa. UNEP-Regional Seas Programme/UNEP-WCMC, Cambridge

Donato DC, Boone Kauffman J, Murdiyarso D, Kurnianto S, Stidham M, Kanninen M (2011) Mangroves among the most carbon-rich forests in the tropics. Nat Geosci 4(5):293-297

Duarte CM, Losada IJ, Hendriks IE, Mazarrasa I, Marbà N (2013) The role of coastal plant communities for climate change mitigation and adaptation. Nat Clim Chang 3(11):961-968

Duarte CM, Middelburg JJ, Caraco N (2004) Major role of marine vegetation on the oceanic carbon cycle. Biogeosciences Discussions, EuropeanGeosciences Union. 1(1):659-679. hal-00297772

ECOWAS-CEDEAO. (2010). "ECOWAS Vision 2020."10

EPA. (2015). Social cost of carbon. http://www3.epa.gov/climatechange/ EPAactivities/economics/scc.html

Fatoyinbo TE, Simard M (2013) Height and biomass of mangroves in Africa from ICESat/GLAS and SRTM. Int J Remote Sens 34(2): 668-681. https://doi.org/10.1080/01431161.2012.712224

Fourqurean JW, Duarte CM, Kennedy H, Marbà N, Holmer M, Mateo MA, Apostolaki ET, Kendrick GA, Krause-Jensen D, McGlathery KJ, Serrano O (2012) Seagrass ecosystems as a globally significant carbon stock. Nat Geosci 5:505-509

GADM (2015). GADM database of Global Administrative Areas. Version 2.5. Davis, CA. http://gadm.org/, GADM, University of California, Davis

Galik CS, Jagger P (2015) Bundles, duties, and rights: a revised framework for analysis of natural resource property rights regimes. Land Econ 91(1):76-90

Galik CS, Cooley DM, Baker JS (2012) Analysis of the production and transaction costs of forest carbon offset projects in the USA. J Environ Manag 112:128-136

Giri C, Ochieng E, Tieszen LL, Zhu Z, Singh A, Loveland T, Masek J, Duke N (2011) Status and distribution of mangrove forests of the world using earth observation satellite data. Glob Ecol Biogeogr 20:154-159

Goldstein A, and Gonzalez G. (2014). Turning over a new leaf: State of the forest carbon markets 2014
Green EP, Short FT (2003) World atlas of seagrasses. Prepared by UNEP world conservation monitoring Centre. University of California, Berkeley, Berkeley

Halpern BS, Walbridge S, Selkoe KA, Kappel CV, Micheli F, D'Agrosa C, Bruno JF, Casey KS, Ebert C, Fox HE, Fujita R, Heinemann D, Lenihan HS, Madin EMP, Perry MT, Selig ER, Spalding M, Steneck R, Watson R (2008) A global map of human impact on marine ecosystems. Science 319(5865):948-952. https://doi.org/10.1126/science. 1149345

Hamilton S (2013) Assessing the role of commercial aquaculture in displacing mangrove forest. Bull Mar Sci 89(2):585-601

Hamilton SE, Casey D (2016) Creation of a high spatio-temporal resolution global database of continuous mangrove forest cover for the 21st century (CGMFC-21). Glob Ecol Biogeogr. https://doi.org/10. 1111/geb.12449

Hamilton SE, Lovette J (2015) Ecuador's mangrove Forest carbon stocks: a spatiotemporal analysis of living carbon holdings and their depletion since the advent of commercial aquaculture. PLoS One 10(3):e0118880

Herr D, and Pidgeon E. (2015). Guidance for national blue carbon activities: fast-tracking national implementation in developing countries. IUCN and CI

Herr D, Agardy T, Benzaken D, Hicks F, Howard J, Landis E, Soles A, Vegh T (2015) Coastal "blue" carbon. A revised guide to supporting coastal wetland programs and projects using climate finance and other financial mechanisms. IUCN, Gland

Hoekstra JM, Molnar JL, Jennings M, Revenga C, Spalding MD, Boucher TM, Robertson JC, Heibel TJ, and Ellison K. (2010). The atlas of global conservation: changes, challenges, and opportunities to make a difference.In J. L. Molnar, editor. University of California Press, Berkeley

Howard, J., Hoyt, S., Isensee, K., Telszewski, M. and Pidgeon, E., 2014. Coastal blue carbon: methods for assessing carbon stocks and emissions factors in mangroves, tidal salt marshes, and seagrasses. http:// www.cifor.org/publications/pdf_files/Books/BMurdiyarso1401.pdf. Last Accessed 1/15/2020

Hutchison J, Manica A, Swetnam R, Balmford A, Spalding M (2014) Predicting global patterns in mangrove forest biomass. Conserv Lett 7(3):233-240

Huxham M, Emerton L, Kairo J, Munyi F, Abdirizak H, Muriuki T, Nunan F, Briers RA (2015) Applying climate compatible development and economic valuation to coastal management: a case study of Kenya's mangrove forests. J Environ Manag 157:168-181

IFAD. 2001. Assessment of rural poverty: Western and Central Africa. Rome

Jardine SL, Siikamäki JV (2014) A global predictive model of carbon in mangrove soils. Environ Res Lett 9(10):104013

Kauffman JB, and RK Bhomia. (2014). How can a little shrimp do so much damage?: ecosystem service losses associated with land cover change in mangroves. AGU Fall Meeting Abstracts

Kristensen E, Bouillon S, Dittmar T, Marchand C (2008) Organic carbon dynamics in mangrove ecosystems: a review. Aquat Bot 89(2):201-219

Lavery PS, Mateo MA, Serrano O, Rozaimi M (2013) Variability in the carbon storage of Seagrass habitats and its implications for global estimates of blue carbon ecosystem service. PLoS One 8:e73748

Lehner B, Döll P (2004) Development and validation of a global database of lakes, reservoirs and wetlands. J Hydrol 296:1-22

McCrea-Strub A, Zeller D, Sumaila UR, Nelson J, Balmford A, Pauly D (2011) Understanding the cost of establishing marine protected areas. Mar Policy 35(1):1-9

Ministerio del Ambiente, CI Ecuador, and IUCN (2015). Workshop Report: Blue carbon and other coastal ecosystem services - Next steps in international and national policy making and implementation

Murray BC, Linwood P, Aaron Jenkins W, and Sifleet S. (2011). Green payments for blue carbon: Economic incentives for protecting 
threatened coastal habitats. Nicholas Institute for Environmental Policy Solutions, Report NI 11 (04)

Nellemann C, and Corcoran E. (2009). Blue carbon: the role of healthy oceans in binding carbon: a rapid response assessment: UNEP/Earthprint

Nigeria, Government of. 1999. Overview of the National Policy on the Environment

Olander LP, Galik CS, Kissinger GA (2012) Operationalizing REDD+: scope of reduced emissions from deforestation and forest degradation. Curr Opin Environ Sustain 4(6):661-669

Patil V, Singh A, Naik N, Unnikrishnan S (2015) Estimation of mangrove carbon stocks by applying remote sensing and GIS techniques. Wetlands: $1-13$

Pendleton L, Donato DC, Murray BC, Crooks S, Jenkins WA, Sifleet S, Craft C, Fourqurean JW, Kauffman JB, Marbà N (2012) Estimating global "blue carbon" emissions from conversion and degradation of vegetated coastal ecosystems. PLoS One 7(9)

Pendleton L, Murray BC, Gordon D, Cooley D, and Vegh T. (2014). 17. Harnessing the financial value of coastal 'blue'carbon. Valuing Ecosystem Services: Methodological Issues and Case Studies:361

Polidoro BA, Carpenter KE, Collins L, Duke NC, Ellison AM, Ellison JC, Farnsworth EJ, Fernando ES, Kathiresan K, Koedam NE (2010) The loss of species: mangrove extinction risk and geographic areas of global concern. PLoS One 5(4):e10095

Rönnbäck P (1999) The ecological basis for economic value of seafood production supported by mangrove ecosystems. Ecol Econ 29(2):235-252

Salem ME, Mercer DE (2012) The economic value of mangroves: a meta-analysis. Sustainability 4(3):359-383

Sanderson EW, Jaiteh M, Levy MA, Redford KH, Wannebo AV, Woolmer G (2002) The human footprint and the last of the wild: the human footprint is a global map of human influence on the land surface, which suggests that human beings are stewards of nature, whether we like it or not. BioScience 52(10):891-904

Serrano O, Lavery PS, Duarte CM, Kendrick GA, Calafat A, York P, Steven A, Macreadie P (2016) Can mud (silt and clay) concentration be used to predict soil organic carbon content within seagrass ecosystems? Biogeosciences 13(17):4915

Siikamäki J, Sanchirico JN, Jardine SL (2012) Global economic potential for reducing carbon dioxide emissions from mangrove loss. Proc Natl Acad Sci 109(36):14369-14374

Spalding M, Kainuma M, and Collins L. (2010). World atlas of mangroves. A collaborative project of ITTO, ISME, FAO, UNEPWCMC, UNESCO-MAB, UNU-INWEH and TNC. London, UK. http://data.unep-wcmc.org/datasets/5: Earthscan
Ullman R, Bilbao-Bastida V, Grimsditch G (2013) Including blue carbon in climate market mechanisms. Ocean \& Coastal Management 83: $15-18$

United Nations. (2015a) General Assembly Resolution A/RES/70/1. Transforming our world: the 2030 Agenda for Sustainable Development. http://www.un.org/ga/search/view_doc.asp?symbol= A/RES/70/1\&Lang=E. Last Accessed 1/15/2020

United Nations. 2015b. Adoption of the Paris Agreement. FCCC/CP/ 2015/10/Add.1.https://unfccc.int/sites/default/files/resource/docs/ 2015/cop21/eng/10a01.pdf. Last Accessed 1/15/2020

UNEP. (2014). The importance of mangroves to people: a call to action. Edited by Emma Sullivan, Jan-Willen von Bochove, Takehiro Nakamura. Cambridge

UNEP_and_CIFOR. (2014). Guiding principles for delivering coastal wetland carbon projects. United Nations environment Programme, Nairobi, Kenya and Center for International Forestry Research, Bogor, Indonesia

UNEP-WCMC, and F. T. Short. (2005). Global distribution of seagrasses (version 3). Third update to the data layer used in Green and Short (2003), superseding version 2. United Nations Environment Programme - World Conservation Monitoring Centre (UNEPWCMC), Cambridge, UK. http://data.unep-wcmc.org/datasets/7

USAID, FCMC, USFS, IP, and IUCN. (2014). Workshop Report: West Africa Regional Workshop on Mangroves and Climate Change

Valiela I, Bowen JL, York JK (2001) Mangrove forests: one of the World's threatened major tropical environments at least $35 \%$ of the area of mangrove forests has been lost in the past two decades, losses that exceed those for tropical rain forests and coral reefs, two other well-known threatened environments. Bioscience 51(10):807-815

Vasconcelos MJ, Cabral AIR, Melo JB, Pearson TRH, de Pereira H, A, Cassamá V, Yudelman T (2014) Can blue carbon contribute to clean development in West-Africa? The case of Guinea-Bissau. Mitig Adapt Strateg Glob Chang: $1-23$

V-C-S. (2015). Methodology for Tidal Wetland and Seagrass Restoration Version 1.0. http://www.v-c-s.org/sites/v-c-s.org/files/VM0033\% 20Tidal $\% 20$ Wetland $\% 20$ and $\% 20$ Seagrass $\% 20$ Restoration $\% 20 \mathrm{v} 1$. 0\%2020\%20NOV\%202015.pdf

Vegh T, Jungwiwattanaporn M, Pendleton L, Murray BC (2014) Mangrove ecosystem services valuation: state of the literature. Duke University, Durham, NC, USA

Publisher's note Springer Nature remains neutral with regard to jurisdictional claims in published maps and institutional affiliations. 